\title{
Linx
}

Revue des linguistes de l'université Paris X Nanterre

$72 \mid 2015$

Former à l'écrit universitaire, un terrain pour la linguistique?

\section{Linguistic Theory in Approaches to Written Error in US Composition: History and Current Directions}

\section{Bruce Horner and Min-Zhan Lu}

\section{(2) OpenEdition \\ Journals}

Electronic version

URL: http://journals.openedition.org/linx/1599

DOI: $10.4000 /$ linx.1599

ISSN: 2118-9692

\section{Publisher}

Presses universitaires de Paris Nanterre

\section{Printed version}

Date of publication: 1 September 2015

Number of pages: $55-72$

ISSN: 0246-8743

\section{Electronic reference}

Bruce Horner and Min-Zhan Lu, « Linguistic Theory in Approaches to Written Error in US Composition History and Current Directions », Linx [Online], 72 | 2015, Online since 01 March 2016, connection on 01 May 2019. URL : http://journals.openedition.org/linx/1599 ; DOI : 10.4000/linx.1599 


\title{
Linguistic Theory in Approaches to Written Error in US Composition : History and Current Directions
}

\author{
Bruce HORNER et Min-Zhan LU \\ University of Louisville, Kentucky, USA.
}

\begin{abstract}
We trace significant shifts over the last forty years in the assumptions about language, language relations, and language learning made by US composition scholars to understand written error through their use of specific theories and findings of scholarship in linguistics, and we explore the implications of these shifts for the teaching of writing. We identify three sets of assumptions with monolingualism, and a fourth set with a break from monolingualist assumptions and an alignment with those associated with translingualism and plurilingualism. Examples from student writing are used to illustrate the implications of these different assumptions for the teaching of writing.
\end{abstract}

Keywords

Error, translingualism, composition, pedagogy, plurilingualism.

In this chapter, we review the ways in which linguistic theory has been applied to the question of written error by U.S. teachers and scholars of postsecondary writing - a field known as "composition." We delineate four approaches to written error in composition. Three of these approaches are aligned with beliefs associated with an ideology of monolingualism : what we call the "eradicationist" approach, the "second language learning" approach, and the "accommodationist" approach. That ideology treats monolingualism as the norm for language both statistically and culturally. The fourth approach responds to shifts in global migration patterns and in the linguistic and social identifications of students and faculty by rejecting monolingualism as either the statistical or cultural norm. Instead, it adopts a framework for understanding and engaging in both spoken and written language variously identified as "plurilingualism," "postmonolingualism," or "translingualism," the term we use. We explore the implications of these competing frameworks for understanding language and language relations for the learning and teaching of writing.

Composition is a field of scientific inquiry restricted primarily to the U.S. that emerged initially as an effort by U.S. writing teachers to better understand and teach writing to undergraduate students in U.S. colleges and universities. It focuses primarily on the course in composition - or academic writing - that most of these students have been required to take during their first year of university study. The initiation of that course and the institutionalization of the requirement that all undergraduate students take that course have been dominated by what we are calling an "eradicationist" approach. This approach is aligned with several key assumptions associated with the ideology of monolingualism : the assumptions that there is a single correct form of language that writers are to use, known as Standard Written English ("SWE") ; that knowledge of that language, once acquired, will remain and is applicable to all situations ; that there is no need to learn any language other than English ; and that any perceived deviation from English represents an error caused by either students' ignorance of correct English or their failure to adequately 
proofread their writing to correct it.

One further assumption behind this approach is that writing is a relatively transparent medium for speech and thought. Thus, this approach takes students' spoken language and thinking to be transmitted directly to their writing. Teachers taking this approach view difficulties they experience in comprehending students' writing as evidence of defects not only in the students' language but also in their thinking. So, for example, particular features of students' writing have been cited as evidence that they remain at a cognitively undeveloped state (Berg, Coleman,1985 ; Lunsford, 1979 ; Hays, 1983 ; Hays, 1988), or that they are trapped in an "oral" rather than "literate" mindset (Farrell, 1978 ; Ong, 1978). As M. Rose (1988) has put it, teachers taking this approach have engaged in "cognitive reductionism" by making facile leaps linking writing to cognition.

We identify this approach as "eradicationist" insofar as those taking it define difference in language as error, and thus something to be eradicated, or else the students themselves are to be eradicated from the university as unable to use language correctly. In the past, those students whose writing was perceived to be different from correct English, or SWE, have been either removed from schools or relegated to special writing classes to remediate them. Not surprisingly, most such students have been members of subordinate ethnic, racial, and class backgrounds. In other words, frequently language difference, redefined as error, has often served as proxy for discrimination against racial and ethnic minorities and those of lower social classes. While nowadays very few scholars of composition would advocate this view, it remains the default approach taken by many composition teachers. Many of these teachers, it is worth emphasizing, are unfamiliar with the findings of scholarship in either composition or linguistics.

The eradicationist approach to language difference enacts monolingualism's identification of nationality and civic and social identity with language, all assumed to be linked and necessarily singular (Gal and Irvine, 1995). In the teaching of composition, monolingualism assumes not only that there is a single form of written language that is correct, but also that writing should be in one language only - in the case of the U.S., English. This is despite the fact that, historically, the U.S. population has always been multilingual, and that legally, at least at the federal level, there is no official national language in the U.S. So, for example, it is commonly assumed that English will be the sole language of instruction, the sole language of texts students are assigned to read, and the sole language of the texts they are assigned to write and the words they are to speak.

The findings of linguistics scholarship radically challenged this eradicationist view. As a consequence of work by W. Labov (1970), G. Smitherman (1972 ; 1986), and others on dialects, compositionists came to recognize that language difference might not always equate to language defect. So, for example, teachers came to recognize that features of African-Americans' speech identified as Black English Vernacular (BEV) dialect were not evidence of defective English but a systematic and logical pattern of language use. In the field of composition, official recognition of the logic of forms of English other than SWE came in the form of "Students' Right to Their Own Language," a 1974 position statement endorsed by the Conference on College Composition and Communication, the flagship national organization of U.S. composition teachers and scholars, and reaffirmed in November 2003. 
This approach adopted a framework from scholarship in applied linguistics on second language learning for understanding difference in students' writing. This second-language learning framework allowed teachers to approach difference, even errors, in students' writing as evidence not of their defective intelligence, effort, or cognitive development. Instead, writers, including native speakers of English, were viewed as comparable to second language learners when attempting to learn to produce the variety of English known as SWE. As M. Shaughnessy put it in describing native English speaking students with writing difficulties (called "Basic Writers"), "B[asic] W[riting] students write the way they do, not because they are slow or non-verbal, indifferent to or incapable of academic excellence, but because they are beginners and must, like all beginners, learn by making mistakes" (1997: 5).

D. Bartholomae's 1980 article "The Study of Error" best exemplifies the kind of understanding resulting from adopting this framework for understanding difference in student writing (see also Bartholomae, 1985 ; Bartholomae :1986 ; Hull, 1986 ; Kroll, Schafer :1978 ; Lees, 1987 ; Tricomi, 1986). Drawing on research in second language learning, Bartholomae analyzed patterns in the errors of writing by students identified as writing at a level of performance below that necessary for doing college-level work. Following the model then current for understanding second language learning, he argued that these patterns were evidence not of laziness, lack of intelligence, or defective grasp of language but, rather, the writer's construction of an interlanguage, consisting of a set of idiosyncratic rules that approximated but did not correlate fully with the conventions for SWE : for example, following an idiosyncratic rule requiring that they insert the word "in" in front of every use of the word "which." Recognizing that writing does not directly represent speech, Bartholomae also compared students' texts with their oral reading of their writing to identify "miscues," or moments when a student's oral reading of his text did not correlate with the written text - for example, when a student read aloud "I would like to write about my experience" for a written text that appeared as "I would to write about my experience." This attention to writers' miscues when reading their own writing highlighted the difficulties writers also face of transcription - difficulties not recognized by those adopting the eradicationist approach to difference, who assumed writing directly represents speech and thought. And this attention to the difficulties of transcription also brought out other patterns of deviations from convention in students' writing that have no direct corollary in speech, such as misspellings and seemingly idiosyncratic uses of punctuation and formatting of text on the page.

Subsequent studies of students' difficulties with error using the framework of second language learning showed that just as the performance of learners of a second language will vary depending on the degree of cognitive or other challenges the speaker is experiencing, likewise students' difficulties producing conventionally correct writing will increase as they take on cognitively demanding tasks - say for example, writing about an unfamiliar topic, or attempting to explain a complex concept (Schwalm, 1985). These studies also showed that many students lacked training in proofreading - that is, they were unpracticed in adopting an orientation to text associated with copyediting, and thus needed guided practice in doing so.

The framework of second language learning provided by applied linguistics resulted in significantly improved ways for composition teachers to understand and address error in students' writing. It enabled teachers to recognize the educability, effort, and intelligence of writers, and it helped teachers enable students to identify and control error in their writing. The framework provided empirical support for understanding written error, and it led to pedagogies 
that were demonstrably more effective in helping students gain control over errors in their writing. However, the understandings of language difference in student writing afforded by this second language learning framework retained several key assumptions of monolingualism. Specifically, as in the eradicationist approach, the second language learning framework assumed 1) monolingualism as the norm toward which students were to aspire ; 2) a stable set of standards for correct writing, and 3) a linear model of development toward language mastery. For example, Bartholomae expressed the hope that his study would help delineate what he called a sequence of "natural" learning toward mastery of written language comparable to the "natural sequence of acquisition for adults learning a second language" (1980:33). Despite this framework's necessary recognition of multiple languages, the framework is directed at enabling learners to achieve native-like fluency in the second language. Thus, any mixing of languages is treated as ultimately to be eliminated - at best evidence of an intermediary stage preceding mastery of the target language or language variety - here, SWE - which is viewed as stable and discrete. The possibilities that this variety of language might change or be changed by its users, that it might intermix with other varieties, or that it might take a multiplicity of forms are not considered.

Further, the second language learning framework is aligned with monolingualism in treating the question of language difference as politically neutral. Difficulties students had learning a second language, or learning to master SWE, were understood in primarily individual cognitive linguistic rather than sociopolitical and sociohistorical terms. So, for example, M. Epes (1985) dismissed the influence of nonlinguistic factors on students' production of written errors, asserting, "There are peculiarly linguistic (as distinct from sociological and psychological) reasons for the severe problems with the written language almost universally experienced by nonstandard dialect speakers" (29), and she asserted this despite the fact that her informants described their difficulties in precisely social and psychological terms : "insecurity," "conflict," "malaise" "selfimage" (Horner, 1992 : 147-49). The appropriateness of SWE was taken as a given rather than a sociohistorical phenomenon that one might legitimately challenge.

There is a variant of the second language learning approach that does recognize asymmetrical relations of power involved in language use and acceptability but that argues for accommodating such relations of power. We term this an accommodationist approach. In this variant, associated most commonly with the work of L. Delpit $(1988,1993)$ and with the phenomenon of codeshifting, status quo power relations are acknowledged but are themselves treated as stable and hence to be accommodated rather than challenged (see also Bean et al., 2003 ; Elbow, 1999). Those taking an accommodationist approach argue that students must be taught SWE precisely because it is the "language of power." Instructors' attention to other language varieties is seen as denying members of subordinated groups access to the language of power, either as a strategy for denying them such access or as a misguided result of liberal tolerance for cultural difference.

However, despite the attention of this approach to relations of power in determining the appropriateness of using language in particular ways, it remains aligned with monolingualist tenets. First, it treats the so-called language of power, as well as language varieties identified as students' "home" languages, as stable, discrete, and internally uniform. Second, it insists on a single social location for each of these language varieties as its appropriate home : BEV on the street, SWE in the classroom and the page. Third, it adopts a commodified notion of language that assumes languages by themselves carry power, rather than locating power in the particular uses to which language is put by readers and writers, speakers and listeners and in the broader 
sociopolitical and sociohistorical relations of these agents - for example, the long and continuing history of racism in the U.S. accounting for and maintaining the lack of power to those positioned as racially outside the U.S. cultural norm. Finally, this approach assumes that the identity of language users is singular, stable, and internally uniform rather than multiple, conflicting, and fluctuating. This assumption has led to ethical dilemmas - if a writer's identity is associated with use of a particular language variety, then any requirement to change the writer's language can be seen as demanding a change to the writer's identity. Thus, as K. Gilyard (1997) has observed, the expectation of code-shifting would appear to demand a kind of linguistic schizophrenia whereby the writer's identity is split between his or her home identity and language, on the one hand, and a "school" identity and language, on the other.

We have argued that despite significant differences in their assumptions about what language difference in writing represents regarding the individuals responsible for producing it, the eradicationist, second language, and accommodationist approaches are aligned with monolingualist ideology in their assumptions that language and social identity are linked, singular, internally uniform, and stable, and in their view of writerly development as proceeding through a natural sequence of stages toward mastery of the "target" language. While the second language learner framework and accommodationist approach do acknowledge the legitimacy of different languages and language varieties, these are accommodated to monolingualism through a strategy of pluralization : instead of just one correct language variety, these posit the legitimacy of many different language varieties each correct, or appropriate, to a specific sphere - English in the U.S., French in France, business writing in business, sociology writing in sociology, BEV at home, SWE at school.

While these three approaches remain dominant in composition teaching in the U.S. (Horner, Trimbur, 2002) and, we suspect, elsewhere, there is also a growing movement in composition scholarship and teaching that adopts an alternative framework for approaching language difference in writing (Canagarajah, 2013a ; Canagarajah, 2013b ; Horner, Lu, Matsuda , 2010 ; Horner, Lu, Royster, Trimbur, 2011 ; Martinez, Young, 2011). This approach is relatively new, having emerged in response to shifts on the ground and in the classroom, and to corresponding shifts in linguistics. The relatively novel status of this approach is signaled by the number of new terms and strategies currently being advanced to name it, including plurilingualism, translingualism, postmonolingualism, and the French diversalité. These terms have been introduced to suggest an alternative to both conventional monolingualism and dominant conceptions of multilingualism : thus plurilingualism, postmonolingualism, and translingualism are offered as alternatives to multilingualism, and diversalité as an alternative to diversité.

Participating in this challenge to monolingualism are challenges to some of the concepts fundamental to traditional theories of second language acquisition, such as "native speaker," "nonnative speaker," "learner," "interlanguage," "multilingualism," and even "language." Adopting a framework for studying language associated with the linguistics of contact that focuses on the "interactional and sociolinguistic dimensions of language" (Firth and Wagner, 1997), scholars have taken the monolingual situation - a single, internally uniform, and shared language among speakers - as at best the exception to the norm rather than the norm itself to which the facts on the ground must adjust. Likewise, composition scholars are coming to recognize the linguistic heterogeneity of students in their classrooms, the faculty teaching them, and the population at large as the norm rather than the exception, and they are coming to 
recognize that monolingual assumptions are inadequate in helping them understand their students, their writing, and their work.

Composition scholars' recognition of linguistic heterogeneity as the norm arises from a number of factors. These include changes in global migration patterns, the increasing reliance of U.S. colleges and universities on tuition from students from abroad as a result of decreased state support for postsecondary education in the U.S., the global spread and fracturing of "English" into a variety of world Englishes, and the rise of global digital communication technologies and networks. As a consequence of these and other factors, students and faculty within the U.S. increasingly know a variety of languages and, as well, a variety of kinds of English, and are less willing to ascribe superiority or stability to the variety known as SWE (Jenkins, 2011). For these same reasons, the monolingualist assumption treating social identity and language use as singular, stable, and linked is under challenge by students and faculty who claim multiple and fluctuating social identities and languages, including languages they may not, by conventional definitions, “own” (for example, Chiang and Schmida, 1999 ; Leung et al., 1997 ; Valdès :1992).

Compositionists have followed two paths in trying to address the plural and fluctuating identifications of language users with languages and, simultaneously, the plural and fluctuating character of categories of language. One movement has argued for treating as legitimate and encouraging the mixing of language types in what is termed code-meshing, distinct from code shifting (Canagarajah, 2006; Martinez, Young, 2011). Those pursuing this movement have argued for designing writing classes that deliberately include students with a mixture of language repertoires, increasing the linguistic repertoires of all students, and encouraging students to mix languages and language varieties within individual texts and to introduce new idioms into their texts.

One problem with this movement is that despite its efforts to challenge monolingualist notions of stable, discrete, and internally uniform languages and language varieties, the very act of asking students to mix them reinforces these notions - as suggested by the notion of "code" itself as a stable and discrete system which one might deploy, or from which one might decode or translate a meaning into a different code (Lu, 2009 ; Vance, 2009). Thus, this approach risks making a fetish of specific textual forms and practices by treating them as carrying specific effects by themselves. Conversely, writing that does not explicitly appear to mix codes is accepted as in fact singular in the codes deployed. This paradoxically reinforces a belief in the stability and discrete character of languages.

To address these limitations, others have argued for treating translingualism - movement across languages - not as a specific strategy to be sought out and encouraged as different from normal language practice but instead as an inevitable, if unacknowledged, feature of all language use. For example, applied linguist A. Pennycook (2008) has argued that English is always a language "in translation," and language itself as being temporally contingent, a "local practice" (Pennycook, 2010). Applied to the teaching of writing, those of us adopting this position argue that translation occurs in every act of writing, including writing that appears simply to iterate ordinary monolingual English, insofar as writers are putting ideas into words, and other words, translating these into new contexts, and re-interpreting those ideas and formulations anew. Writing teachers adopting this position direct their efforts at helping students to identify the different in the seemingly "same." This is often done by highlighting the temporally different location of 
iterations that appear simply to repeat commonplaces, and by identifying the mixing of language resources - at the level of lexicon, syntax, organization, format, and genre - in texts traditionally perceived to be linguistically singular and internally uniform. Those adopting this position argue that writers exercise agency both when they introduce seemingly new linguistic forms into their writing and when they appear merely to iterate conventional forms. In either case, writers are seen not as writing in a language but as always rewriting the language with each utterance. Emphasis is then placed on why a writer might choose to re-create a specific locution as opposed to alternatives, for what purposes and under what conditions.

For example, when one of our students invented the nonidiomatic locution "can able to" to express having both the permission and the ability to do something, and also when she revised this to the more idiomatic "may be able to" (Lu, 1994), this perspective would see both as instances of the student exercising agency and rewriting English. This perspective thus resolves the apparent ethical dilemma presented by the accommodationist approach of why students should be asked to produce conventional forms of language in their writing. From a translingual perspective, students are not giving up agency but exercising it both when they produce unconventional locutions and when they reproduce conventional forms.

We will close with three strategies advocated for advancing a translingual pedagogy. First, there is a need to be open to the possibility that seemingly unconventional forms of writing represent not error but a rewriting of English. Here, for example, are two passages written by our students in which the writers use nonidiomatic phrases :

From a Native Daughter is an essay by Trask in which she spills out her heritage and upbringing, trying to prove injustice amongst the cultural history of Hawaii.

Both Trask and Lasch use language as a stepping stool.

Horner had initially thought these were errors : instead of "spills," "spells" ; and instead of "stools," "stones." But in fact, Horner's students corrected him, explaining that they meant spills to highlight the force of Trask's language, and that for them - leading primarily urban lives stepping stools were more appropriate than stepping stones.

Second, we can identify instances that go unnoticed of mixing of languages and genres in texts thought to exemplify pure examples of English because of the text's canonical status. Below, for example, we see H. Thoreau (1854) - who in the U.S. is seen as an exemplary writer of American English - mixing languages and snatches of song in his book Walden :

It is a fool's life, as they will find when they get to the end of it, if not before. It is said that Deucalion and Pyrrha created men by throwing stones over their heads behind them :

- Inde genus durum sumus, experiensque laborum,

Et documenta damus qua simus origine nati.

Or as Raleigh rhymes it in his sonorous way, -

"From thence our kind hard-hearted is, enduring pain and care,

Approving that our bodies of a stony nature are."

Third, we can show that writers are always negotiating with readers about the acceptability of 
their seemingly unconventional uses of language. Below, for example, we see Thoreau again in the opening of his book negotiating with readers to accept his use of the first person pronoun "I unconventional during his time.

I will therefore ask those of my readers who feel no particular interest in me to pardon me if I undertake to answer some of these questions. . . . In most books, the I, or first person, is omitted ; in this it will be retained. . . . Unfortunately, I am confined to this theme by the narrowness of my experience.

Of course, from a $21^{\text {st }}$ century perspective, Thoreau may be granted allowance, as a "creative" writer, for such breaks from convention. But we can find comparable breaks with "normal" practice in other, more ostensibly orthodox writing. For instance, Thomas Kuhn, among the most influential $20^{\text {th }}$-century historians of science, opens an article laying the groundwork for his landmark Structure of Scientific Revolutions (1962b) with the caution, "I can best approach my particular topic by explaining that the subject itself may well seem extraordinarily odd" (1962a), and through the article, he deploys references to untranslated French and German texts. Given evidence of such canonical authors engaging in such negotiation and mixing of languages, we can then ask why these writers also, at other times, iterate seemingly conventional writing. We can then pose these same questions to students for them to consider in their own writing : what to negotiate, and why ; and whether and how and why to use what kind of language in what text, whether deemed conventional or not. Often enough, and for legitimate communicative purposes, students may want to identify practices common among a specific discipline and to opt to iterate the conventional forms of language of that discipline in their writing. But seeing this as a choice rather than a requirement will encourage them to explore the logic behind and to be more critically sensitive to the forms they choose - conventional or not - and thus to deploy them more thoughtfully. As the introduction of the terms "translingual," "plurilingual," and "diversalité" into academic scholarship illustrates, conventional nomenclature is sometimes inadequate to represent conceptual changes and hence must be revised.

This is not to deny that, in the contemporary "postmonolingual" condition (Yildiz, 2012), writers need to be prepared for the continuing demand by some readers for "standard" usage, especially of those writers deemed subordinate, and even when those making the demand cannot identify what that "standard" is or its purpose (Coupland, 2000 ; Lees, 1989 ; Williams, 1981). Students are quite aware of such demands, to the point of seeing themselves as having no choice at all in their writing, which they often approach as a matter of following rules set by others. Nor is it to deny the legitimacy of students' and other writers' desire to incorporate and make use of what currently seems common practice into their own writing. Accommodation, in this specific sense, is itself a common practice in addressing language difference. But it is to reject mistaking what may appear to be the current common language practices of some for universal, unchanging, and uniform standards for language by which writing is to be judged. Students who follow such beliefs are less likely to make productive use of all forms of writing, conventional or not, insofar as they do not consider the rhetorical logic of using these. Linguist L.-J. Calvet (2006) reminds us that, on the one hand, language is the ongoing outcome of practices, but, on the other hand, representations of language affect practices and, hence, language. Thus how we represent language to students affects their practices with and on language. For this reason, writers must be seen as inevitably always rewriting language rather than writing within a predetermined and unchanging language, and as always exercising agency and responsibility for all their writing, 
seemingly conventional or not, to encourage responsible contributions from students to the life of the language with every word they write.

We have argued that three approaches to language difference - eradicationist, second-language learning, and accommodationist - remain tied to an ideology of monolingualism insofar as they retain notions of languages as stable, discrete, and internally uniform each appropriate to a discrete social and geopolitical location, and notions of language users' identities as likewise fixed and linked to a single language. Linguistics has contributed to challenging the eradicationist view of language difference in writing among compositionists as always a sign of error and defect, thanks especially to work in applied linguistics on second-language acquisition. Challenges within the field of applied linguistics to such concepts as native language and native speaker, language competence, and even language are likewise enabling compositionists to further challenge concepts of language drawn from monolingualist ideology expressed in ideas of writers writing in a language. These challenges have helped compositionists to shift their focus to how writers always write across languages, even when appearing not to do so. Insofar as both linguistics and the field of composition must respond to recent dramatic changes in the linguistic environment and practices of language users, we anticipate that compositionists will continue to benefit significantly from and build on the field of linguistics.

\section{Bibliography}

BARTHOLOMAE, D., 1980, “The study of error", College Composition and Communication, 31, p. 253-69.

BARTHOLOMAE, D., 1985, "Inventing the university", dans M. Rose (dir.), When a writer can't write : Studies in writer's block and other composing process problems, New York, Guildford, p. 134-65.

BARTHOLOMAE, D., 1986, "Released into language : Errors, expectations, and the legacy of Mina Shaughnessy", dans D. McQuade (dir.), The territory of language : Linguistics, stylistics, and the teaching of composition, Carbondale, Southern Illinois Univ, Press, p. 65-88.

BEAN, J. et al., 2003, "Should we invite students to write in home languages ?", Composition Studies, 31-1, p. 25-42.

BERG, A., COLEMAN, G., 1985, "A cognitive approach to teaching the developmental student", Journal of Basic Writing, 4-2, p. 4-23.

CALVET, L-J., 1999/2006, Pour une écologie des langues du monde, Paris, Plon, Toward an ecology of world languages, Trans. Andrew Brown, Cambridge, Polity.

CANAGARAJAH, A., 2006, "The place of world englishes in composition : Pluralization continued ",College Composition and Communication, 57, p. 586-619.

CANAGARAJAH, A., 2013a, Translingual Practice : Global Englishes and Cosmopolitan Relations, New York, Routledge.

CANAGARAJAH, A. (ed.), 2013b,_Literacy as Translingual Practice : Between Communities and Classrooms, New York, Routledge.

CHIANG, Y., SCHMIDA, M., 1999, "Language identity and language ownership : Linguistic conflicts of first-year university writing students", dans L. Harklau, K. Losey, M. Siegl (dir.), Generation 1.5 meets college composition : Issues in the teaching of writing to U.S.-educated learners of ESL, Mahwah, NJ, Erlbaum, p. 81-96.

COUPLAND, N., 2000, "Sociolinguistic prevarication about 'standard English", Journal of Sociolinguistics, 4-4, p. 622-34. 
DELPIT, L., 1988, “The silenced dialogue : Power and pedagogy in educating other people's children”, Harvard Educational Review, 58, p. 280-98.

DELPIT, L., 1993, “The politics of teaching literate discourse”, dans T. Perry, J. Fraser J. (dir.), Freedom 's plow: Teaching in the multicultural classroom, New York, Routledge, p. 285-95.

ELBOW, P., 1999, "Inviting the mother tongue”, JAC, 19, p. 359-88.

EPES, M., 1985, "Tracing errors to their sources : A study of the encoding processes of adult basic writers", Journal of Basic Writing, 4, p. 4-33.

FARRELL, T., 1978, "Developing literacy : Walter J. Ong and basic writing”, Journal of Basic Writing, 2-1, p. 30-51.

FIRTH, A., WAGNER, J., 1997, "On discourse, communication, and (some) fundamental concept in SLA research”, Modern Language Journal, 81, p. 285-300.

GAL, S., IRVINE, J., 1995, "The boundaries of languages and disciplines : How ideologies construct difference”, Social Research, 62-4, p. 967-1001.

GILYARD, K., 1997, “Cross-Talk : Toward transcultural writing classrooms”, dans C. Severino, J. Guerra, J. Butler (dir.), Writing in multicultural settings, New York, Modern Language Association, p. 325-31.

GUERRA, J., 2012, "From code-segregation to code-switching to code-meshing : Finding deliverance from deficit thinking through language awareness and performance", dans P. Duston, L. Gambrell, K. Headley, S. Fullerton, P. Stecker P. (dir.), 61st Yearbook of the Literacy Research Association, Oak Creek, WI, Literacy Research Association, p. 108-118.

HAYS, J., 1983, “The Development of discursive maturity in college writers", dans J. Hays, P. Roth, J. Ramsey, R. Foulke (dir.), The writer's mind : Writing as a mode of thinking, Urbana, IL, NCTE, p. 127-44.

HAYS, J., 1988, "Socio-cognitive development and argumentative writing: Issues and implications from one research project", Journal of Basic Writing, 7-2, p. 42-67.

HORNER, B., 1992, "Rethinking the 'sociality' of error : Teaching editing as negotiation”, Rhetoric Review, 11, p. 172-99

HORNER, B., LU, M., 1999, Representing the "other" : Basic writers and the teaching of basic writing, Urbana, IL, National Council of Teachers of English, p. 139-165.

HORNER, B., TRIMBUR, J., 2002, «English only and US college composition », College Composition and Communication, 53, p. 594-630.

HORNER, B., LU, M., MATSUDA, P. (dir.), 2010, Cross-language relations in composition, Carbondale, Southern Illinois Univ. Press.

HORNER, B., LU, M., ROYSTER, J., TRIMBUR, J., 2011, "Language difference in writing : Toward a translingual approach", College English, 73-3, p. 303-21.

HULL, G., 1986, "Acts of wonderment : Fixing mistakes and correcting errors", dans D. Bartholomae, A. Petrosky (dir.), Facts, artifacts and counterfacts : Theory and method for a reading and writing course, Upper Montclair, NJ, Boynton/Cook, p. 199-226.

JENKINS, J., 2011, “Accommodating (to) ELF in the international university", Journal of Pragmatics 43, p. 926-36.

KROLL, B., SCHAFER, J., 1978, "Error analysis and the teaching of composition", College Composition and Communication, 29, p. 242-48.

KUHN, T., 1962a, "Historical structure of scientific revolutions", Science, 136, p. 760-64.

KUHN, T., 1962b, The structure of scientific revolutions, Chicago, Univ. of Chicago Press.

LABOV, W., 1970, "The logic of nonstandard English", dans A. Cashdan, E. Grugeon (dir.), Language in education: A source book, London, Routledge.

LEES, E., 1987, "Proofreading as reading, errors as embarrassments", dans T. Enos T. (dir.), A 
Sourcebook for basic writing teachers, New York, Random, p. 216-30.

LEES, E., 1989, “' "The exceptable way of the society': Stanley Fish's theory of reading and the task of the teacher of editing", dans P. Donahue, E. Quandhal (dir.), Reclaiming pedagogy: The rhetoric of the classroom, Carbondale, Southern Illinois Univ. Press, p. 144-63.

LEUNG, C., HARRIS, R., RAMPTON, B., 1997, "The idealised native speaker, reified ethnicities, and classroom realities”, TESOL Quarterly, 31-3, p. 543-75.

LU, M., 1994, "Professing multiculturalism : The politics of style in the contact zone", College Composition and Communication, 45, p. 442-58.

LU, M., 2009, "Metaphors matter : Transcultural literacy”, J AC, 29-1.2, p. 285-93.

LUNSFORD, A., 1979, "Cognitive development and the basic writer", College English, 41, p. 38-46.

MARTINEZ, A., YOUNG, V. (dir.), 2011, Code Meshing as World English : Policy, pedagogy, performance, Urbana, IL, National Council of Teachers of English.

ONG, W., 1978, "Literacy and orality in our times", ADE Bulletin, 58, p. 1-7.

PENNYCOOK, A., 2008, "English as a language always in translation", European Journal of English Studies, 12-1, p. 33-47.

PENNYCOOK, A., 2010, Language as a local practice, London, Routledge.

ROSE, M., 1988, "Narrowing the mind and page : Remedial writers and cognitive reductionism", College Composition and Communication, 39, p. 267-302.

SCHWALM, D., 1985, "Degree of difficulty in basic writing courses : Insights from the Oral Proficiency Interview Testing Program”, College English, 47-6, p. 629-40.

SHAUGHNESSY, M., 1977, Errors and expectations : A guide for the teacher of basic writing, New York, Oxford Univ. Press.

SMITHERMAN, G., 1972, "Black power is black language", dans G.M. Simmons, H.D. Hutchinson, H.E. Summons (dir.), Black culture : Reading and writing Black, New York, Holt, p. $85-91$.

SMITHERMAN, G., 1986, Talkin and testifyin : The language of Black America, Detroit, Wayne State Univ, Press.

THOREAU, H., 1995 [1854]), Walden ; or, life in the woods, New York, Dover [Boston, Ticknor].

TRICOMI, E., 1986, “Krashen's second-language acquisition theory and the teaching of Edited American English", Journal of Basic Writing, 5-2, p. 59-69.

VALDÈS, G., 1992, "Bilingual minorities and language issues in writing: Toward profession wide responses to a new challenge", Written Communication 9-1, p. 85-136.

VANCE, J., 2009, "Code-meshing meshed codes : Some complications and possibilities", JAC, 29-1.2, p. 281-84.

YILDIZ, Y., 2012, Beyond the mother tongue: The postmonolingual condition, New York, Fordham Univ. Press.

WILLIAMS, J., 1981, “The phenomenology of error", College Composition and Communication, 32-2, p. 152-68. 